\title{
Study of Batik Wastewater Treatment Using PAC (Poly Aluminum Chloride) as Coagulant and Organoclay (Montmorillonite-polydadmac) as Floccullant to Reduce Total Suspended Solid (TSS) and Total Dissolved Solid (TDS)
}

\author{
Novita Chandra Sari*, Irwan Nugraha** \\ Chemistry Department, Faculty of Science and Technology, UIN Sunan Kalijaga Yogyakarta \\ J1. Marsda Adisucipto No 1 Yogyakarta 55281, Indonesia. Tel. +62-274-540971, Fax. +62-274-519739. \\ Email: novitachandrasari@gmail.com*, irwan.nugraha@uin-suka.ac.id**
}

\begin{abstract}
Sari N C, Nugraha I. 2017. Study of Batik Wastewater Treatment Using PAC (Poly Aluminum Chloride) as Coagulant and Organoclay (Montmorillonite-polydadmac) as Floccullant to Reduce Total Suspended Solid (TSS) and Total Dissolved Solid (TDS). Proc Internat Conf Sci Engin 1: 125-130. Batik wastewater treatment using PAC (Poly Aluminium Chloride) as a coagulant and organoclay (montmorillonite- polyDADMAC) as flocculants was investigated in this study. The purpose of this study was to analyze the quality of batik wastewater effluent before and after coagulation-flocculation and analyze the effectiveness of organoclay as flocculants of batik wastewater. Organoclay (montmorillonite-polyDADMAC) synthesised by reacting natural bentonite with polyDADMAC $0.4 \%$. Coagulation and flocculation used jar test method with a speed stirring at $120 \mathrm{rpm}$ for 2 minutes and slow stirring at $40 \mathrm{rpm}$ with a variety of types, masses of flocculants and flocculation time. At first, batik wastewater had high levels of TSS and TDS levels. TSS and TDS levels reduced after coagulation-flocculation. Effectiveness of maximum TSS reduced at 99,74\% with the addition of organoclay flocculant $2.5 \mathrm{~g} / \mathrm{L}$ and flocculation time for 80 minutes. Effectiveness of maximum TDS reduced at $93,57 \%$ with the addition of organoclay flocculant $2.5 \mathrm{~g} / \mathrm{L}$ and 60 minutes flocculation.
\end{abstract}

Keywords: Organoclay, montmorillonite-polyDADMAC, polymer, flocculant, batik wastewater, intercalation, bentonite

\section{INTRODUCTION}

The fashion development in Indonesia has spurred the textile industry development, the example is the batik industry. Batik was recognized by UNESCO as a world cultural heritage from Indonesia. The process of batik manufacture produced wastewater. Batik wastewater from batik coloring process has the potential to damage the environment. Based on observations and interviews with batik business people, the conditions show most of the batik industry are not to process the wastewater before thrown away. This is because the wastewater processing techniques is expensive and difficult. Batik wastewater was produced the environment pollute because it has BOD (Biological Oxygen Demand) at $960 \mathrm{mg} / \mathrm{L}, \mathrm{COD}$ (Chemical Oxygen Demand) at 1800 $\mathrm{mg} / \mathrm{L}$, TSS (Total Suspended Solid) at $540 \mathrm{mg} / \mathrm{L}$, TDS (Total Dissolved Solid) at $1672 \mathrm{mg} / \mathrm{L}, \mathrm{pH} 13$ and temperature $30{ }^{\circ} \mathrm{C}$ (Pratiwi, et al. 2014).

Batik wastewater is an organic wastewater that has a high concentration of $\mathrm{pH}, \mathrm{BOD}, \mathrm{COD}$, TSS, and TDS. One of dye used in the colloring process of batik is golden yellow and black remazol. The compound is only used about 5\% and 95\% will be disposed (Suprihatin, 2014).

Before disposal must to treated the wastewater because the concentration of COD, TSS, TDS, and turbidity are high and exceed the quality standard of batik wastewater. Batik wastewater treatment to reduce the environmental pollution. The batik wastewater treatment are chemically, biologically, and physics. Chemical processes include flocculation, adsorption, and coagulation. Physical processes include screaning, filtration, and membrane technology. Biological process with the activity of microorganisms and aquatic plants (Kurniawan, 2013)

Coagulation-flocculation process is a wastewater treatment to wastewater that containing hazardous chemical compounds from the coloring process (Gillespie, et al., 1970). Coagulation is a process of destabilizing colloidal particles by the addition of coagulants and stirring at high speed. A cationic coagulant is added to the water which forms the attraction force among the suspended particles. Flocculation is the process of forming clumps of solids in a solution (flocs) (Suharto, 2011).

Coagulation-flocculation process is done by adding polymers/surfactant as coagulants and flocculants to remove organic compounds and strengthen flocs. PAC (poly aluminum chloride) is a compound used as a coagulant. PolyDADMAC is a cationic polymer that can be utilized as a flocculant in water treatment (Bolto, B., et al., 2007). However, based on CAS: 26062, polyDADMAC is deficient because the boiling point value is $100^{\circ} \mathrm{C}$, so if waste treatment applied in hightemperature will damage the structure of polyDADMAC.

The addition of clays such as bentonite is good used as a flocculant in the waste treatment process. One of the utilization is as flocculant in paper wastewater 
processing (Gillespie, et al., 1970). The material can also be used in various applications according to the specification of the surface area and structure of clay type (Malik, 2003). Bentonite producer in Indonesia is very much and almost in all town but the utilization not optimal (Prasetyo, 2007).

Bentonite is a mineral of alumina silicate hydrate which is included in pilosilicate or silicate plated with Tetrahedral: Octahedral ratio $=2: 1$. The composition of bentonite is dominated by montmorillonite $(85 \%)$ and beidellite. Bentonite can be utilized as an adsorbent because has expandability and large surface area so it can accumulate metal ions and organic compounds (Konta, 1995).

Bentonite deficiency is easy to absorb water and less stable when used as an adsorbent. The expansion of the lattice from bentonite can be enhanced by modifying bentonite become organoclay minerals. Ganigar, et al. (2010) was modified the polydiallyldimethylammonium chloride (polyDADMAC) cationic surfactant with montmorillonite (MMT) to adsorb trichlorophenol and trinitrophenol from river wastewater. The modified bentonite produces organoclay with a larger lattice area.

Research needs to be done for batik wastewater treatment to reduce the concentration of TSS and TDS in batik wastewater using bentonite modification (montmorillonite-polyDADMAC) as flocculants and coagulation process using PAC (poly aluminum chloride). The expectation of this reasearch was produced the batik wastewater that below the quality standard (the decision of the governor of DIY No. 7 of 2010).

\section{MATERIALS AND METHODS}

\section{Materials}

This research used natural bentonite. The batik wastewater effluent used in this research from Kabul Art Gallery in Yogyakarta. The cationic surfactant used for modification is Polydiallyldimethylammonium chloride (polyDADMAC) $40 \%$.

\section{Preparation of Organoclay}

Natural bentonite was added distillated water. A suspension of natural bentonite in distillated water was stirred for $1 \mathrm{~h}$ on magnetic stirrer at $70{ }^{\circ} \mathrm{C}$ to remove a soluble inorganic salts and any adhering materials. The natural bentonit suspension were modified with polyDADMAC $0,4 \%$ by adding amounts of surfactant was stirred for $3 \mathrm{~h}$ on magnetic stirrer at $65^{\circ} \mathrm{C}$. Then the suspension was fitered, washed with hot distillated water and then dried at $80^{\circ} \mathrm{C}$ for $18 \mathrm{~h}$. The product (organoclay) was grinded and sized to get a particle size of 109 microns.

\section{Analytical Methods}

The composition of natural bentonite and organoclay was determined with FTIR and XRD. FTIR pectra for natural bentonite and organoclay were obtained using
FTIR Shimadzu Prestige-21. XRD for natural bentonite and organoclay were obtained using XRD Shimadzu 600.

\section{Coagulation and Flocculation Experiments}

Coagulation and flocculation in this study used jar test methods. The batik wastewater was diluted up to $20 \mathrm{x}$. The batik wastewater as much $500 \mathrm{~mL}$ was inserted in a $1 \mathrm{~L}$ beaker. Then added PAC 1,5 g/L as coagulant and stirred for 2 minutes on magnetic stirrer at constantly speed $120 \mathrm{rpm}$. After coagulation added flocculant with mass and type variation, then stirred for variation time on constantly speed $10 \mathrm{rpm}$. The mixture was precipitated at $1 \mathrm{~h}$. A supernatant was analyzed parameter TSS (SNI 06-6989.03-2004) and TDS (SNI 06-6989.27-2004) concentration of batik wastewater.

\section{Flocculant Type Variation}

Coagulation and flocculation experiment with variation of type flocculant. The type of flocculant are montmorillonite-polyDADMAC (organoclay), natural bentonite, and polyDADMAC with the same mass $2,5 \mathrm{~g} / \mathrm{L}$

\section{Flocculant Mass Variation}

Coagulation and flocculation experiment with variation of mass flocculant. The mass of flocculant are $0,5 \mathrm{~g} / \mathrm{L}, 1$ $\mathrm{g} / \mathrm{L}, 1,5 \mathrm{~g} / \mathrm{L}, 2 \mathrm{~g} / \mathrm{L}$, dan 2,5 g/L with natural bentonite and montmorillonite-polyDADMAC (organoclay) as flocculant.

\section{Flocculation Time Variation}

Coagulation and flocculation experiment with variation of flocculation times. Flocculation used montmorillonite-polyDADMAC (organoclay) $2,5 \mathrm{~g} / \mathrm{L}$ as flocculant at 20, 40, 60, 80, 100 minutes.

\section{RESULTS AND DISCUSSION}

\section{Modification of (Organoclay) Montmorillonite- polyDADMAC}

Montmorillonite-polyDADMAC was synthesized with method of Anirudhan, et.al. (2015). MontmorillonitepolyDADMAC was synthesized by natural bentonite dispersed into distilated water to occur swelling between bentonite layers, so that in bentonite dispersions can receive metal ions and organic compounds, including polyDADMAC. The cations on the interlayer will be replaced by the $\mathrm{N}$ group of polyDADMAC. The cation exchange process at $65^{\circ} \mathrm{C}$ so that the cation exchange reaction is faster and more optimal.

The results from the reaction between polyDADMAC and natural bentonite is a paste organoclay. The formation of the paste indicates that polyDADMAC has reacted with natural bentonite. Organoclay dried at $80^{\circ} \mathrm{C}$ to evaporate distilation water dispersed in organoclay. The dried organoclay was crushed and filtered using a 109 micron sized filter to has the same size and expand the surface. The results of 
montmorillonite-polyDADMAC

synthesized (organoclay) were compared to their physic with natural bentonite before modified with polyDADMAC. Montmorillonite-polyDADMAC (organoclay) has a darker color than natural bentonite before modified.

\section{FTIR (Fourier Transform Infrared Spectroscopy)}

Characterization using the FTIR instrument to determine the functional groups in natural bentonite and montmorillonite-polyDADMAC (organoclay). Figure 1 shows the FTIR spectra in the $4000-400 \mathrm{~cm}-1$ wavelength range. The specific vibrational energy of each element will be indicated by the magnitude of the infrared wave number on the FTIR spectra. From the FTIR spectra of montmorillonite-polyDADMAC (organoclay) and natural bentonite, there can be a shift in the absorption of wave numbers in some functional groups.

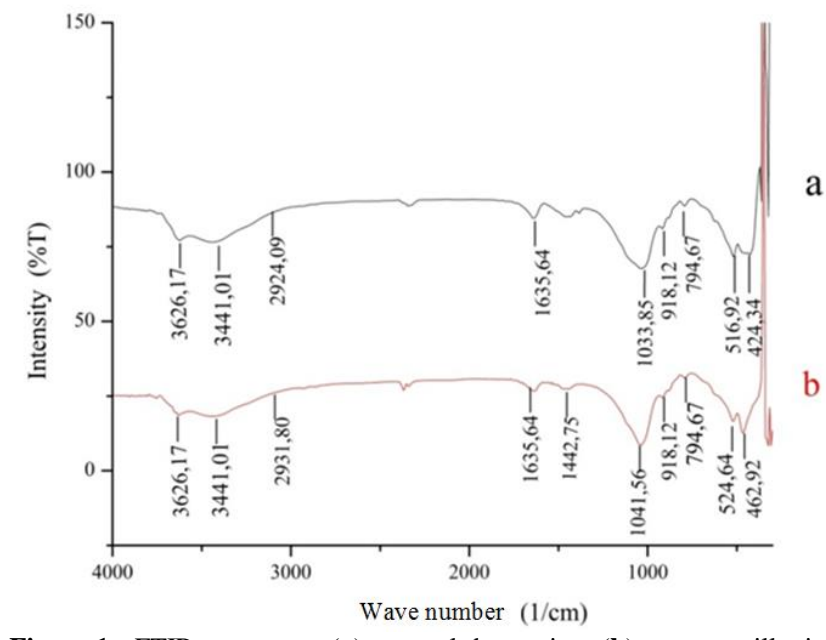

Figure 1. FTIR spectrum (a) natural bentonite, (b) montmorillonitepolyDADMAC.

There was a shift in the vibration of $\mathrm{Si}-\mathrm{O}-\mathrm{Si}$ from $1033,85 \mathrm{~cm}-1$ to $1041,56 \mathrm{~cm}-1$, vibration buckling of SiO-Al from $516,92 \mathrm{~cm}-1$ to $524,64 \mathrm{~cm}-1$, and bending vibration of Si-O-Si from 424,34 cm-1 to $462,92 \mathrm{~cm}-1$. Reaction of bentonite with cationic surfactant resulted the shift of the wave number. The FTIR spectra showed that no decomposed functional group in the sample and the structure of the bentonite does not change.

PolyDADMAC has a specific vibration at 3332.5 $\mathrm{cm}-1$ which is a vibration of $\mathrm{OH}$ and $1644.2 \mathrm{~cm}-1$ is the vibration of C-N (Mwangi I.W., et al., 2013). The presence of polyDADMAC in organoclay cannot be shown in the FTIR spectra because the polyDADMAC interaction on bentonite is an ion-exchange reaction. There is overlaping of functional groups of FTIR spectra between polyDADMAC surfactant and natural bentonite. Analysis using FTIR cannot show functional groups of polyDADMAC.

Based on the FTIR spectra of natural bentonite and montmorillonite-polyDADMAC, can be concluded that no significant changes in wave numbers and functional groups. The shift of wave numbers is a sign that the interacted bentonite with polyDADMAC is cation exchange.

\section{XRD (X-Ray Diffraction)}

Characterization using XRD is method for bentonite characterization. Qualitative characterization using XRD to determine the types of minerals from natural bentonite and montmorillonite-polyDADMAC (organoclay). In the XRD difactogram (Figure 2) natural bentonite has diffraction peaks at $2 \theta$ of $6.10 ; 20.20$ and 26.9o with a basal spacing at $14.48 \AA, 4.38 \AA$, and 3.31 $\AA$. While the spesific diffraction peaks organoclay at $2 \theta$ is $5.7 \mathrm{o} ; 19.7 \mathrm{o}$; and $26.4^{\circ}$ with a basal spacing at 15.49 $\AA, 4.51 \AA$, and $3,37 \AA$.

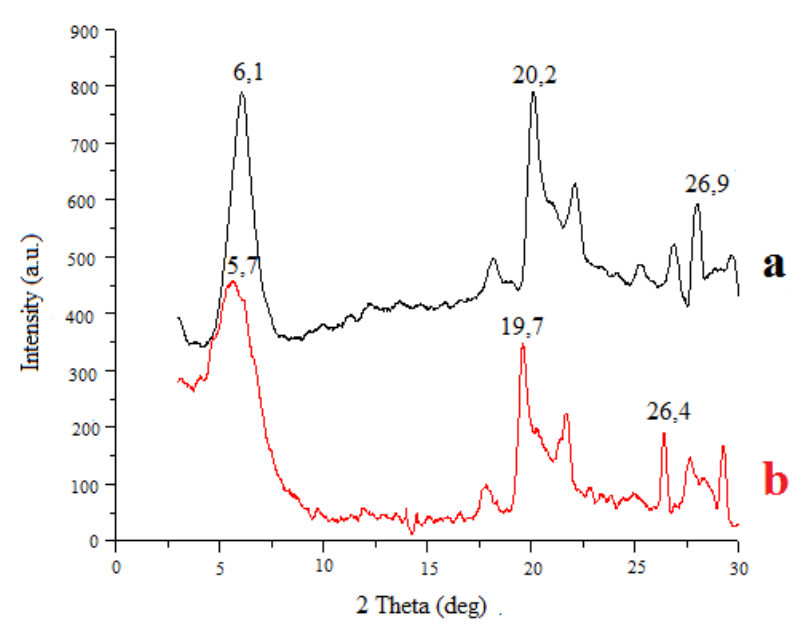

Figure 2. XRD diffractogram (a) natural bentonite; (b) montmorillonitepolyDADMAC.

Table 1. Comparison of $2 \Theta$ and basal spacing on natural bentonite and montmorillonite-polyDADMAC.

\begin{tabular}{llll}
\hline \multicolumn{2}{l}{ Natural bentonite } & \multicolumn{2}{l}{$\begin{array}{l}\text { Montmorillonite- } \\
\text { polyDADMAC}(\text { organoclay })\end{array}$} \\
\hline $2 \Theta$ & $\mathrm{d}(\AA)$ & $2 \Theta$ & $\mathrm{d}(\AA)$ \\
6,1 & 14,4773 & 5,7 & 15,49233 \\
20,2437 & 4,3831 & 19,6738 & 4,50879 \\
26,93 & 3,31 & 26,3933 & 3,37416 \\
\hline
\end{tabular}

The basal spacings was shifted because of interaction between natural bentonite with polyDADMAC. The research by Shen, Dazhong, et al. (2009) produces organoclay with a shift of diffraction peaks to the left. The shift to the smaller diffraction peaks indicates that the cation of the polyDADMAC replaces the cation on the natural bentonite interlayer. Table 1 assumed that montmorillonite-polyDADMAC (organoclay) has been successfully synthesized by intercalation reaction.

The organic compounds location in organoclay depends on the size of the organic compound cation, the length of the alkylammonium ion chain, and the layer charge of the clay (Bergaya, F., et al, 2016). Montmorillonite-polyDADMAC has been successfully synthesized by monolayer intercalation reaction because 
has a basal spacing at $15.49233 \AA$ equivalent to 1.54923 nm.

\section{Effectiveness of montmorillonite-polyDADMAC (organoclay) as Flocculant to Reduced TSS and TDS of Batik Wastewater}

TSS (Total Suspended Solid) are particles suspended have a negative impact to aquatic ecosystem. TSS take a long time to precipitate and not through a filter (Fardiaz, 1992). The batik wastewater must be in accordance with the batik wastewater quality standard. The TSS level of batik wastewater quality standard based on the decision of the DIY governor number 7 on 2010 is less than 200 $\mathrm{mg} / \mathrm{L}$. TSS levels of batik wastewater the beginning has a high TSS level at $7145 \mathrm{mg} / \mathrm{L}$, while the TDS level at $8080 \mathrm{mg} / \mathrm{L}$. In this research used batik wastewater with 20x dilution which has a high levels of TSS at 5716 $\mathrm{mg} / \mathrm{L}$ and a high levels of TDS at $6920 \mathrm{mg} / \mathrm{L}$ and not feasible to disposal and must to processed.

This research used variation of flocculant types, flocculant mass, and flocculation contact time to investigate the effectivity of montmorillonitepolyDADMAC flocculant (organoclay) to reduce TSS and TDS levels of batik wastewater. Flocculant types used montmorillonite-polyDADMAC (organoclay), natural bentonite, and polyDADMAC. The variation of flocculant types resulted in different TSS and TDS levels for each treatment.

\section{Variation of Flocculant Type}

Table 2 showed the montmorillonite-polyDADMAC (organoclay) flocculant is the best of flocculants to reduce TSS levels. Treatment with natural bentonite flocculants and polyDADMAC polymers is not able to reduce TSS and TDS in accordance with the batik wastewater quality standard. Batik wastewater with TSS levels at $25 \mathrm{mg} / \mathrm{L}$ and effektivness of TSS reduce at $99.5626 \%$ is feasible to be disposal because less than batik wastewater quality standard.

Table 2. Effectiveness of TSS levels reduce with variation of flocculant types.

\begin{tabular}{lll}
\hline Flocculant types & $\begin{array}{l}\text { TSS levels } \\
(\mathbf{m g} / \mathbf{L})\end{array}$ & $\begin{array}{l}\text { Effectiveness } \\
(\boldsymbol{\%})\end{array}$ \\
\hline $\begin{array}{l}\text { Montmorillonite- } \\
\text { polyDADMAC (organoclay) }\end{array}$ & 25 & 99,5626 \\
$\begin{array}{l}\text { Natural Bentonite } \\
\text { PolyDADMAC }\end{array}$ & 250 & 95,6263 \\
\hline
\end{tabular}

Table 3 showed the montmorillonite-polyDADMAC (organoclay) flocculant is the best flocculants to reduce TDS levels. Batik wastewater with TDS levels at 585 $\mathrm{mg} / \mathrm{L}$ and evectiveness of TDS reduce at $91,5460 \%$ is feasible to be disposal because less than batik wastewater quality standard. This suggests that montmorillonite-polyDADMAC flocculant is a higher effectiveness than polyDADMAC flocculants and natural bentonite. Organoclay flocculant has a better performance because has a polymer on the interlayer that can bind to compounds contained in batik wastewater. Organoclay also has a function as an adsorbent because has a pores that can adsorb the compounds in batik wastewater.

Table 3. Effectiveness of TDS levels reduce with variation of flocculant types.

\begin{tabular}{lll}
\hline Flocculant types & $\begin{array}{l}\text { TDS levels } \\
(\mathbf{m g} / \mathbf{L})\end{array}$ & $\begin{array}{l}\text { Effectiveness } \\
(\boldsymbol{\%})\end{array}$ \\
\hline $\begin{array}{l}\text { Montmorillonite- } \\
\text { polyDADMAC } \\
\text { (organoclay) }\end{array}$ & 585 & 91,5460 \\
$\begin{array}{l}\text { Natural bentonite } \\
\text { PolyDADMAC }\end{array}$ & 960 & 86,1272 \\
\hline
\end{tabular}

\section{Variation of Flocculant Mass}

Flocculants that used are montmorillonitepolyDADMAC (organoclay) and natural bentonite. The result of wastewater treatment of batik with variation of flocculant mass according to the Figure 3 and 4.

Table 4. TSS levels with variation of flocculant mass.

\begin{tabular}{lll}
\hline $\begin{array}{l}\text { Flocculant } \\
\text { Mass } \\
(\mathbf{g} / \mathbf{L})\end{array}$ & $\begin{array}{l}\text { TSS with Addition } \\
\text { Natural Bentonite } \\
(\mathbf{m g} / \mathbf{L})\end{array}$ & $\begin{array}{l}\text { TSS with Addition } \\
\text { Organoclay } \\
(\mathbf{m g} / \mathbf{L})\end{array}$ \\
\hline 0,5 & 710 & 620 \\
1,0 & 325 & 555 \\
1,5 & 260 & 315 \\
2,0 & 215 & 100 \\
2,5 & 250 & 25 \\
\hline
\end{tabular}

Table 5. TDS levels with variation of flocculant mass.

\begin{tabular}{llc}
\hline $\begin{array}{l}\text { Flocculant } \\
\text { Mass }(\mathbf{g} / \mathbf{L})\end{array}$ & $\begin{array}{l}\text { TDS with addition } \\
\text { natural bentonite } \\
(\mathbf{m g} / \mathbf{L})\end{array}$ & $\begin{array}{l}\text { TDS with addition } \\
\text { Organoclay } \\
(\mathbf{m g} / \mathbf{L})\end{array}$ \\
\hline 0,5 & 1560 & 1595 \\
1,0 & 1510 & 1335 \\
1,5 & 1100 & 1125 \\
2,0 & 985 & 790 \\
2,5 & 960 & 585 \\
\hline
\end{tabular}

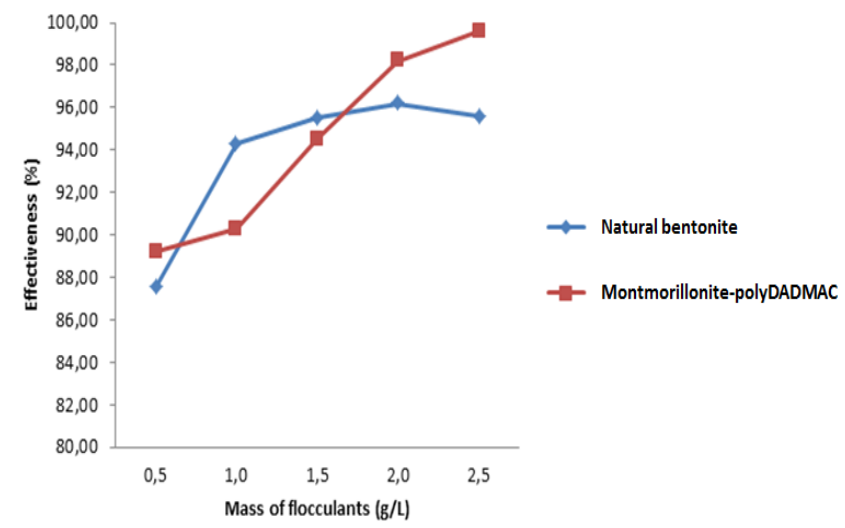

Figure 3. Influence of flocculant mass with effektiveness of TSS reduction. 


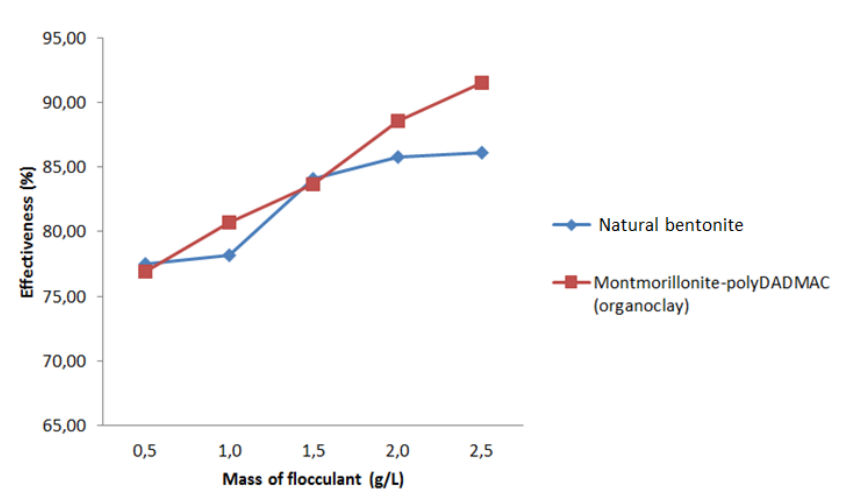

Figure 4. Influence of flocculant mass with effektiveness of TDS reduction.

Figure 3 and 4 are the maximum effectiveness of TSS and TDS reduced with addition of natural bentonite and montmorillonite-polyDADMAC flocculant. The mass used $2.5 \mathrm{~g} / \mathrm{L}$. TSS levels was reduced up to 25 $\mathrm{mg} / \mathrm{L}$ while TDS levels up to $585 \mathrm{mg} / \mathrm{L}$. Its feasible to be disposal because less than batik wastewater quality standard. This suggests that montmorillonitepolyDADMAC flocculants are better than natural bentonite flocculants to reduced TSS and TDS levels of batik wastewater. Organoclay flocculant has a better performance because has a polymer on the interlayer that can bind to compounds contained in batik wastewater. Organoclay also has a function as an adsorbent because has a pores that can adsorb the compounds in batik wastewater.

\section{Variation of Flocculation Contact Times}

Table 6. TSS levels based on variation of flocculation times.

\begin{tabular}{ll}
\hline $\begin{array}{l}\text { Flocculation } \\
\text { Times (menit) }\end{array}$ & TSS levels $(\mathbf{m g} / \mathbf{L})$ \\
\hline 20 & 125 \\
40 & 25 \\
60 & 20 \\
80 & 15 \\
100 & 20 \\
\hline
\end{tabular}

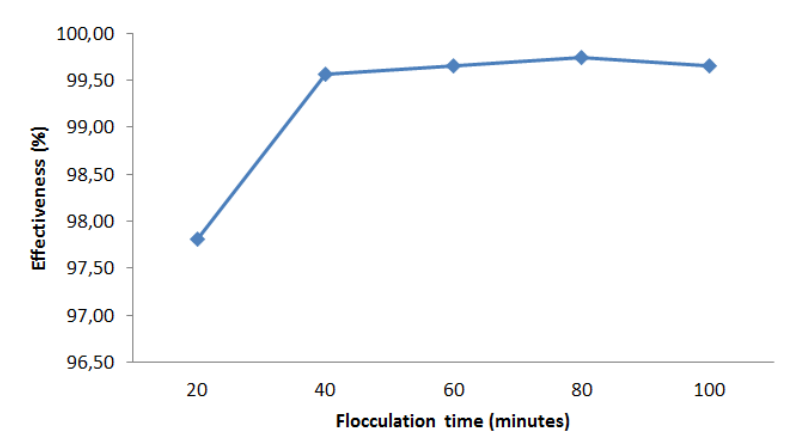

Figure 5. Influence of flocculation times with effektiveness of TSS reduction.

Figure 5 shows the infuence of flocculation times with effektiveness of TSS reduction. This treatment used
2,5 g/L of montmorillonite-polyDADMAC flocculant (organolclay). Effectiveness of maximum TSS reduced at $99,74 \%$ with the addition of organoclay flocculant 2.5 $\mathrm{g} / \mathrm{L}$ and flocculation time for 80 minutes.

Table 7. TDS levels based on variation of flocculation times.

\begin{tabular}{ll}
\hline $\begin{array}{l}\text { Flocculation } \\
\text { Times (menit) }\end{array}$ & TDS levels $(\mathbf{m g} / \mathbf{L})$ \\
\hline 20 & 980 \\
40 & 585 \\
60 & 445 \\
80 & 320 \\
100 & 455 \\
\hline
\end{tabular}

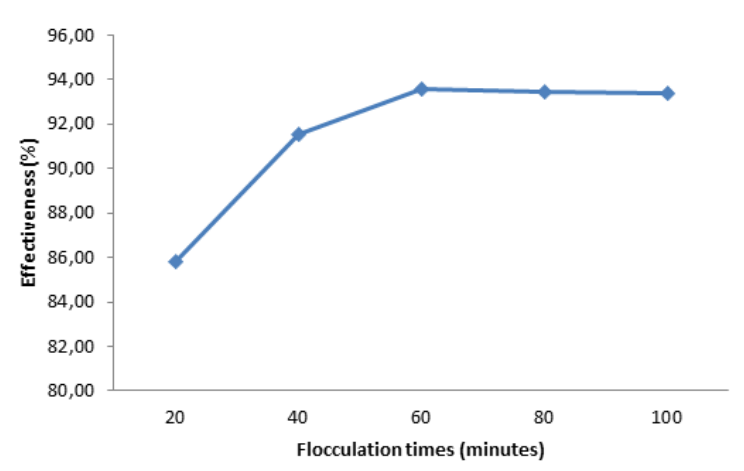

Figure 6. Influence of flocculation times with effektiveness of TDS reduction.

Figure 6 shows the effectiveness of maximum TDS reduced at $93,57 \%$ with the addition of organoclay flocculant $2.5 \mathrm{~g} / \mathrm{L}$ and 60 minutes flocculation. If contact is too long cause the formed of flocks was decomposed again and more likely to form aggregates with wastewater. In addition, because all parts of the organoclay cannot binding the flock again.

\section{CONCLUSIONS}

1. TSS and TDS concentration of batik wastewater effluent before coagulation-flocculation is 7145 $\mathrm{mg} / \mathrm{L}$ and $8080 \mathrm{mg} / \mathrm{L}$, it means the concentration exceeds the quality standard.

2. TSS and TDS concentration of batik wastewater effluent after coagulation-flocculation with organolay flocculant is below the quality standard.

3. Organoclay characterization used FTIR and XRD indicates that modification of natural bentonite and polyDADMAC was succesfull with monolayer intercalation reaction.

4. Effectiveness of maximum TSS reduced at $99,74 \%$ with the addition of organoclay flocculant $2.5 \mathrm{~g} / \mathrm{L}$ and flocculation time for 80 minutes. Effectiveness of maximum TDS reduced at $93,57 \%$ with the addition of organoclay flocculant $2.5 \mathrm{~g} / \mathrm{L}$ and 60 minutes flocculation. 


\section{REFERENCES}

Anirudhan dan Ramachandra. 2015. Adsorptive Removal of Basic Dyes from Aqueous Solutions by Surfactant Modified Bentonit Clay (Organoclay): Kinetic and Competitive Adsorption Isotherm. Process Safety and Enviromental Protection. Vol. 95. Science Direct. Page 215-225.

Bergaya, F., Theng B.K.G., Lagaly G., 2006. Handbook of Clay Science. Developments in Clay Science. Vol. 1. Elsevier.

Bolto, B, J. Gregory. 2007. Organic Polyelectrolytes in Water Treatment. Water. Vol. 41. Page 2301-2324

Fardiaz, Srikandi. 1992. Polusi Air dan Udara. Yogyakarta: Kanisius.

Ganigar, R., Rytwo, G., Gonen, Y., Radian, A., Mishael, Y.G., 2010. Polymer-Clay Nanocomposites for the Removal of Trichlorophenol and Trinitrophenol from Water. Applied Clay Science. Vol. 49. Science Direct. Page 311-316.

Gillespie, W. J., Mazzola, C.A., Marshall, D.W., 1970. Review of Strach Problems as Related to Stream Pollution. Paper Trade Journal. Vol. 154. Page 29-32.

Konta, J. 1995. Clay and Man: Clay Raw Materials in the Service of Man. Applied Clay Science. Vol. 10. Science Direct. Page. 275-335.
Kurniawan, M., W. 2013. Kajian Pengolahan Air Limbah Sentra Industri Kecil dan Menengah Batik dalam Perspektif Good Governance Di Kabupaten Sidoharjo. Prosiding Seminar Nasional Pengolahan Sumberdaya Alam dan Lingkungan 2013. Page 501-508.

Malik, P. K. 2003. Use of Activated Carbon Prepared from Sawdust and Rice-Husk for Adsorption of Acid Dyes :A Case Study of Acid Yellow 36. Dyes and Pigments. Vol. 56. Science Direct. Page 239-249.

Prasetyo A. dan Avisena N., 2007. Lempung Menguak Rahasia Keagungan Allah, UIN-Malang Press, Malang, page 107-110.

Pratiwi, Y., Santoso, G., Waluyo, J., 2014. IbM Kelurahan Gulurejo (Kawasan Pengrajin Batik untuk Mengatasi Masalah Penc emaran Lingkungan Akibat Limbah Cair Batik. Jurnal Teknologi Technoscientia. Vol. 7. Page 38-45.

Shen, Dazhong. 2009. adsorption kinetic and isotherm of anionic dyes onto organo-bentonite from single and multisolute systems. Journal of Hazardous Materials. Vol 172, page 99107

Suharto. 2011. Limbah Kimia: dalam Pencemaran Udara dan Air. Yogyakarta: ANDI

Suprihatin, H. 2014. Kandungan Organik Limbah Cair Industri Batik Jetis Sidoarjo Dan Alternatif Pengolahannya. Jurnal Kajian Lingkungan. No. 2. Vol. 2. Page 130-138 